$14^{\text {th }}$ Conf. Agric. Develop. Res., Fac. of Agric., Ain Shams Univ.,

March, 2019, Cairo, Egypt

Special Issue, 27(1), 17 - 26, 2019

Website: http://strategy-plan.asu.edu.eg/AUJASCl/

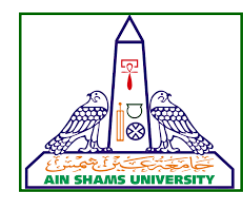

\title{
EVALUATION OF PHYTOCHEMICAL COMPOUNDS IN Moringa oliefera Lam. EXTRACTS ON CYTOTOXICITY OF MCF-7 CELL LINE
}

\author{
Marwa S. Abd El Alem ${ }^{1}$, Ali S.H. ${ }^{2}$, Sarwat M.I. ${ }^{2}$ and Hussein S.H. ${ }^{1}$ \\ 1. Medicinal and Aromatic Plants Dept., Horticulture Research Institute, Agriculture Re- \\ search Center, Giza, Egypt \\ 2. Agric. Biochemistry Dept., Fac. of Agric., Ain Shams Univ., P.O. Box 68 Hadyek Shoubra \\ 11241, Cairo, Egypt
}

${ }^{*}$ Corresponding author: marwa.saad54@yahoo.com

Received 18 February, 2019, $\quad$ Accepted 21 February, 2019

\begin{abstract}
Moringa olifera Lam. which called "Miracle tree" was an enormous usage of medical, nutritional and economic benefits so its leaves and roots extracts were vitro examined for phytochemicals contents, antioxidant, and cytotoxicity against MCF-7 cell line. Leaves and roots both extracts were estimate using 2,2-di phenyl-1-picryl hydrazyl (DPPH) radical scavenging assay and high performance liquid chromatography (HPLC) to determine phenolic and flavonoids compounds. The leaves aqueous and ethyl acetate extracts contained a significantly $(p<0.05)$ more phenolic compounds than root extracts, while roots ethyl acetate extracts were significantly more active in DPPH assay comparing with aqueous extracts. However, the leaves aqueous extract and roots ethyl extracts were contained high values flavonoids compound but in case of phenolic compounds the aqueous roots ex tract recorded the greatest highest number followed by the leaves ethyl acetate extract. The ethyl acetate extractions for leaves and roots have a high inhibition percentage against breast adenocarcinoma MCF-7 cell line comparing with aqueous extracts.
\end{abstract}

Keywords: Antioxidant, MCF-7 cell line, HPLC, Moringa olifera leaves and roots, ethyl acetate extract

\section{INTRODUCTION}

The few decades have seen side effect of chemical drugs on human health and increasing ecological pollutant. Also, depending of peoples on fast foods and bad behaviors in nutrition all of this leads to appearance several diseases due to formation of free radical in bio-systems. So, approximately $80 \%$ of the world population turns to using medicinal plants which consider one of curative and against harmful diseases. Moringa oleifera Lam. is the most vastly cultivated species of monogeneric family, moringaceae which is local to the sub-Himalayan tracts of India, Pakistan, Bangladesh and Afghanistan, Fahey (2005). This rapidlygrowing tree was also utilized by the ancient Romans, Greeks and Egyptians against diseases. It is now widely cultivated and has become naturalized in many locations in the tropics. All Moringa oleifera parts are edible and have long been utilized by human beings Fuglie (1999). Moringa oleifera leaves are well-known to have numerous good biological activities, as reported by lqbal and Bhanger (2006), Chumark et al (2008). Gupta et al (1999) mentioned that Moringa oleifera Lam. Methanol extraction of root showed central nervous system depressant action.

Many studies have investigated that some naturally occurring phytochemical agents, such as phenolic compounds (e.g. alkaloids and flavonoids), specifically those ingested in the human beings diet, trigger cancer-cell death machineries and can be used as chemo preventive candidates against certain cancerous cell types Goodman (2000), Gao et al (2002), Ahmed et al (2015) and Abd-Rabou (2016).

Chumark et al (2008) and Singh et al (2009). stated that Moringa oleifera Lam. is a rich source of antioxidant, as, its aqueous extracts of in some plant parts performance as an antioxidant. Lalas and Tsaknis (2002) and Siddhuraju \& Becker (2003) concluded that Moringa oleifera Lam freeze 
dried leaves. has different high amount of extraction, such as methanol and ethanol with 65.1 and $66.8 \%$, respectively. Moringa oleifera Lam. has a more strong anticancer plant beside several bioactive compounds (e.g., niazimicin and thiocarbamate) with discovered significant antitumor bounce, Guevaraa et al (1999).

So, this study was conducted to evaluate effect of different extracts of Moringa oleifera Lam. against cancer disease.

\section{MATERIALS AND METHODS}

\section{Plant material}

Moringa oleifera dry powder: Both dry powder of leaves and roots were kindly obtained from $\mathrm{Na}$ tional Center for Research (NCR), Giza, Egypt.

\section{Preparation of Moringa oleifera extracts}

Organic extraction of Moringa oleifera Lam. powder of leaves and roots was carried out by ethyl acetate according to the method described by Harbone (1984).

The residue was weighted and the yield percentage was calculated, then the residue was stored at $4^{\circ} \mathrm{C}$ to be ready for using.

Aqueous Moringa olifera Lam. extract was prepared according the method of Shah et al (2015).

\section{Determination of phenolic compound}

Total phenolic compounds were determined with Folin-Ciocalteu reagent using Gallic acid as a standard according to the method described by Singleton and Rossi (1965).

\section{Determination of antioxidant activity}

\section{DPPH radical scavenging assay}

The scavenging effect of crude extracts of Moringa oleifera Lam. leaves and roots on DPPH radical was estimated according to Jain et al (2008).

The radical scavenging activity was determined based on percentage inhibition of absorbance, which was calculated using the following equations:

(\%) $\mathrm{DPPH}$ radical scavenging activity $=\left[\left(\mathrm{A}_{\text {control }}{ }^{-}\right.\right.$ $\left.\left.A_{\text {sample }}\right) /\left(A_{\text {control }}\right) \times 100\right]$
Separation and quantification of phenolic compounds and flavonoids.

High pressure liquid chromatography (HPLC) analysis carried out at the Food Technology Institute, Agriculture Research Center (NRC), Giza, Egypt. According to the method of Goupy et al (1999).

In-vitro studies (Cell culture, maintenance and sub-culture)

The in- vitro cytotoxicity assay was assessed in the cell culture lab, Faculty of Agriculture, Cairo University, According to the method of Repetto et al (2008).

\section{A- Cultivation, propagation and adaptation}

Breast cancer MCF-7cell lines and cultured using Dulbecco's modified Eagle's Medium (DMEM), and Complete media: DPBS supplemented with 10 $\%$ Fetal bovine serum (Sera Lab) $+1 \%$ antibiotic, i.e. penicillin $\mathrm{G}$ potassium+ streptomycin (sigma). Cells were cultured in $5 \% \mathrm{CO}_{2}$ at $37^{\circ} \mathrm{C}$ then treated with $0.25 \%(w / v)$ trypsin/EDTA to affect cell release from the culture flask. After washing the cells with phosphate buffered saline (PBS), to get rid of media.

\section{B- Sub-culturing, counting and plating}

After formation of a complete healthy cell sheet, the cells were harvested by trypsinization using 1 to $2 \mathrm{ml}$ warm $\left(37^{\circ} \mathrm{C}\right), 0.5 \%$ trypsin-EDTA in order to lysis between cells but EDTA playing important role in removing $\mathrm{Mg}^{+2}, \mathrm{Ca}^{+2}$ ions which help in adhering cells with-ve ions in flask surface. So, cells fell apart surface. The trypsin reaction was stopped after 2 min by addition of $10 \mathrm{ml} \mathrm{com-}$ plete media containing 10\% FBS. The detached cells were harvested by centrifugation at $2000 \mathrm{rpm}$ for 10 min using falcon tubes. The cell pellet was re-suspended in $1 \mathrm{ml}$ of fresh complete media containing $10 \%$ FBS. The number of viable cells was counted using short-term viability assay and $0.4 \%$ trypan blue (1:1) was used to stain dead cells and examined under microscope using hemocytomete. The number of viable cells was not less than $80 \%$.

\section{C- Testing of the cells for cytotoxicity}

First day: a cell suspension containing 25.000 cells was delivered to each well of a 96 well microliter tissue culture plate and incubate at $37^{\circ} \mathrm{C}$ in a 

cytotoxicity of MCF-7 cell line

humidified carbon dioxide chamber (5\%) for $24 \mathrm{~h}$ in order to allow the cells to attach to the plate surface and to grow normally. Then, examinations of cells were performing to detect contamination and apoptosis on cell replication.

Second day: the aqueous and ethyl acetate extracts of (leaves and roots) Moringa Olifera with concentration 100, 200 and $400 \mu \mathrm{g} /$ well were applied in triplicates were adding with $1 \%$ antibiotic without using BSA to known effect of extract only. But, in negative control complete media (10\% Fetal bovine serum $+1 \%$ antibiotic) and positive control using (Doxorubicin $\mathrm{HCl} 3 \mu \mathrm{g} / \mathrm{ml}$ ) as chemotherapy and incubate at $37^{\circ} \mathrm{C}$ in a humidified carbon dioxide chamber $(5 \%)$ for $24 \mathrm{~h}$ in order to examined toxicity test.

Third day; Toxicity test: the culture media was removed $0.2 \mathrm{ml}$ of Dulbecco 's phosphate buffered saline solution (DPBS) containing $0.01 \%$ neutral red dye was added to each well to penetrate viable cells and binding with lysosome, and the cells were incubated for an additional 2-4 h. De-stained step; the dye was removed and the cells were washed once with DPBS. Then, $0.2 \mathrm{ml}$ of $50 \%$ ethanol in $1 \%$ acetic acid was added to each well. After, gentle shaking for 30 minutes at room temperature, the absorbance at $570 \mathrm{~nm}$ was measured by Ellissa instrument.

High concentration: indicate to cell viability.

Negative control: instead red colour.

Toxicity case: red colour diluted.

Calculation: percentage of viability cell $=\left(A_{\text {sample }} /\right.$ A $\left._{\text {control }}\right) \times 100$

\section{RESULTS AND DISCUSSIONS}

The results listed in Table (1). Showed that total phenols yield in aqua-leaves $(43.02 \pm 3.77 \mu \mathrm{g} / \mathrm{ml})$ was higher than aqua-roots $(26.05 \pm 1.98 \mu \mathrm{g} / \mathrm{ml})$ extracts. While, ethyl-roots extracts $(20.78 \pm 0.92$ $\mu \mathrm{g} / \mathrm{ml}$ ) showed the lowest total phenols content comparing with ethyl-leaves and aqua-extracts. It can be noticed that total phenols of the two different extracts of Moringa olifera Lam. under study were significantly $(p \leq 0.05)$ differed due to depending on type of solvent. This may be due to the differences in the polarity of the solvents used; such observation was in agreement with the finding of Unuigbe et al (2015)

The results listed in Table (1) present DPPH free radical scavenging activity of aqueous and ethyl acetate extracts of Moringa olifera Lam.

Compared to vitamin $\mathrm{C}$ as a reference antioxidant. The highest percentage of antioxidant activity comparing with vitamin C followed by ethyl-roots extract and aqua-extract. These obtained results showed that the ethyl-roots extract has higher scavenging activity $(82.75 \pm 4.37 \%)$ than ethylleaves extract $(79.61 \pm 7.2 \%)$.While, aqua-leaves extract showed the lowest scavenging activity $(66.65 \pm 1.45 \%)$ compared with aqua-roots and ethyl acetate extract.

Generally, it could be concluded that ethyl acetate extract possessed the highest antioxidant activity comparing with aqueous extract of Moringa olifera Lam. higher antioxidant of ethyl acetate and aqueous extracts may be due to the presence of high content of antioxidant phenol in phenolic sample extract as mentioned before, these results were agreement with Charoensin (2014).

Table 1. Yield and activity of antioxidant phenolic compounds of Moringa oleifera Lam. leaves and root on dry weight basis.

\begin{tabular}{|c|c|c|c|c|}
\hline \multicolumn{5}{|c|}{ Moringa oleifera Lam. Extracts } \\
\hline & \multicolumn{2}{|c|}{$\begin{array}{c}\text { Aqueous Extracts } \\
10 \mathrm{~g} / 100 \mathrm{ml}\end{array}$} & \multicolumn{2}{c|}{$\begin{array}{c}\text { Ethyl acetate Ex- } \\
\text { tracts } 400 \mathrm{mg} / \mathrm{Kg}\end{array}$} \\
\cline { 2 - 5 } & Leaves & Roots & Leaves & Roots \\
\hline Phenolic com- & $43.02 \pm$ & $26.05 \pm$ & $29.09 \pm$ & $20.78 \pm$ \\
pounds $(\mu \mathrm{g} / \mathrm{ml})$ & $3.77^{\mathrm{a}}$ & $1.98^{\mathrm{bc}}$ & $0.91^{\mathrm{b}}$ & $0.92^{\mathrm{c}}$ \\
DPPH (\%A.A) & $66.65 \pm$ & $75.33 \pm$ & $79.61 \pm$ & $82.75 \pm$ \\
& $1.45^{\mathrm{b}}$ & $7.32^{\mathrm{a}}$ & $7.20^{\mathrm{a}}$ & $4.34^{\mathrm{a}}$ \\
\hline
\end{tabular}

Each value represents the average of three replicates \pm stander errors.

The small letter compared in rows and the same letters means non-significant effect at $p<0.05$ significant level.

Therefore, it's more beneficial as a medicinal plant for alternative anticancer drugs and nutraceutical products, Igbo et al (2015). Leelavinothan (2007) and Abas et al (2015) conducted that $M$. oleifera have antioxidant indicates, so the plant could be promising agent in scavenging free radicals.

Cytotoxic effect of Moringa oleifera Lam. aqueous and ethyl acetate extracts of leaves and roots.

The percent value of viability cell concentration (MCF-7) cell line of applied moringa extracts listed in Table (2) and illustrated in Figs. (1a-n).

This data refers to inhibition \% of ethyl acetate extract of $M$. oleifera roots and leaves $93-69 \%$ inhibition respectively, showing higher Inhibition percent than aqueous one at concentration $400 \mu \mathrm{g} / \mathrm{ml}$. In contrast to the trends noted for \%viability the ethyl acetate extract for roots and leaves denoted 
decrease in viability percent of the cells. We can reason that, due to contain compounds that have selective proliferative activity in different cancer cell lines specially MCF-7 under study. The anticancer activity of ethyl acetate roots and leaf extract of $M$. oleifera may in part be attributed to the presence of phenolic compounds in the plant as reported by (Khalafalla et al 2010).
In addition to its anticancer properties, $M$. oleifera is also, a potent antioxidant Das sujoy et al (2012) and Verma et al (2012) and portrays a wide spectrum antibiotic activity Peixoto et al (2011). Pathogenic slides from (3a) to (30) were in accordance with the results illustrated in Table (2).

Table 2. Cytotoxic effect of Moringa oleifera Lam. aqueous and ethyl acetate extractS of Leaves and Roots.

\begin{tabular}{|c|c|c|c|c|c|c|c|c|}
\hline \multirow{2}{*}{ Treatments } & \multicolumn{9}{|c|}{ Viability \% } & \multicolumn{4}{c|}{ Inhibition \% } \\
\cline { 2 - 9 } & $\begin{array}{c}\text { Ethyl. } \\
\text { leaves }\end{array}$ & $\begin{array}{c}\text { Ethyl. } \\
\text { Roots }\end{array}$ & $\begin{array}{c}\text { Aqua } \\
\text { leaves }\end{array}$ & $\begin{array}{c}\text { Aqua } \\
\text { roots }\end{array}$ & $\begin{array}{c}\text { Ethyl. } \\
\text { leaves }\end{array}$ & $\begin{array}{c}\text { Ethyl. } \\
\text { Roots }\end{array}$ & $\begin{array}{c}\text { Aqua } \\
\text { leaves }\end{array}$ & $\begin{array}{c}\text { Aqua } \\
\text { roots }\end{array}$ \\
\hline 100 & 55 & 65 & 76 & 75 & 45 & 35 & 24 & 25 \\
200 & 46 & 50 & 75 & 74 & 54 & 50 & 25 & 26 \\
400 & 31 & 6.0 & 69 & 71 & 69 & 94 & 31 & 26 \\
\hline
\end{tabular}

Each value represents the average of three replicates.

Ethyl acetate sample was dissolved first in DMSO.

Aqua: Aqueous extract. Ethyl: Ethyl acetate extract.

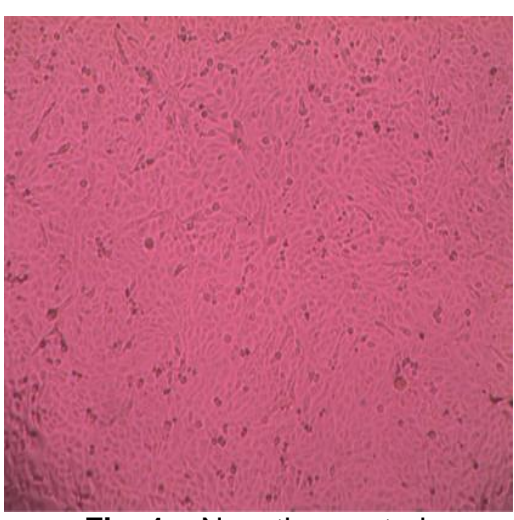

Fig. 1a. Negative control.

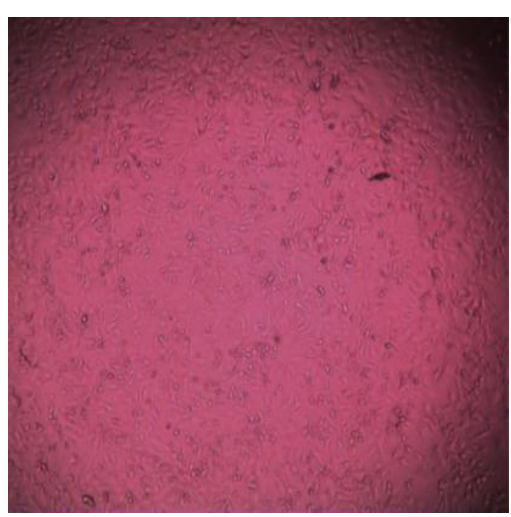

Fig. 1b. Positive control MCF-7 cells.

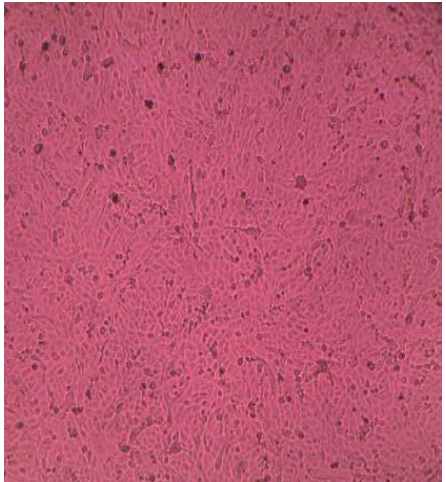

Fig. 1c. Aqua-Leaves $(100 \mu \mathrm{g} / \mathrm{ml})$

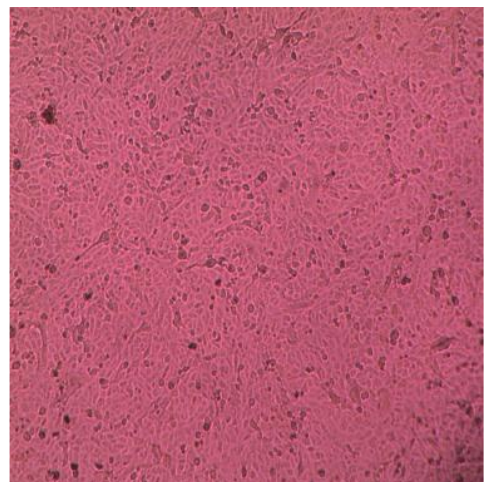

Fig. 1d. Aqua-Leaves $\mu \mathrm{g} / \mathrm{ml})$.

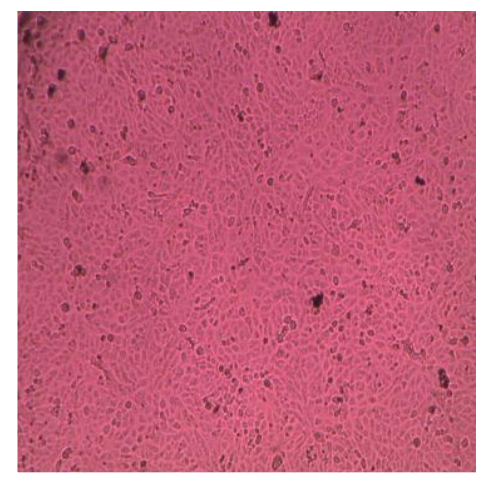

Fig. 1e. Aqua-Leaves $(400$ $\mu \mathrm{g} / \mathrm{ml})$. 

cytotoxicity of MCF-7 cell line

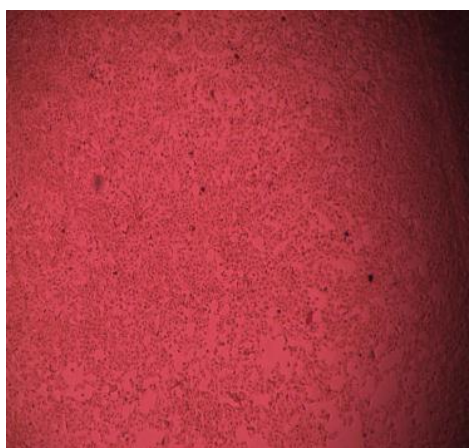

Fig. 1f. Ethyl-Leaves $(100 \mu \mathrm{g} / \mathrm{ml})$

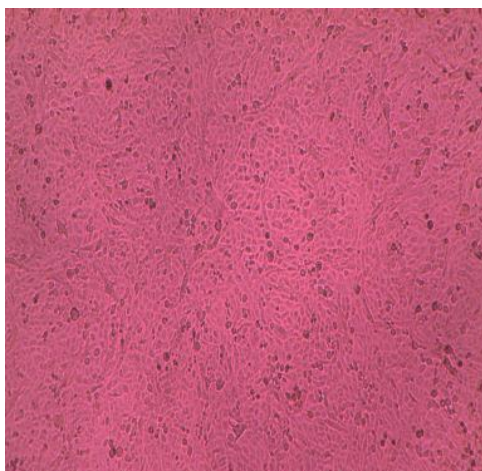

Fig. 1i. Aqua Roots $(100 \mu \mathrm{g} / \mathrm{ml})$

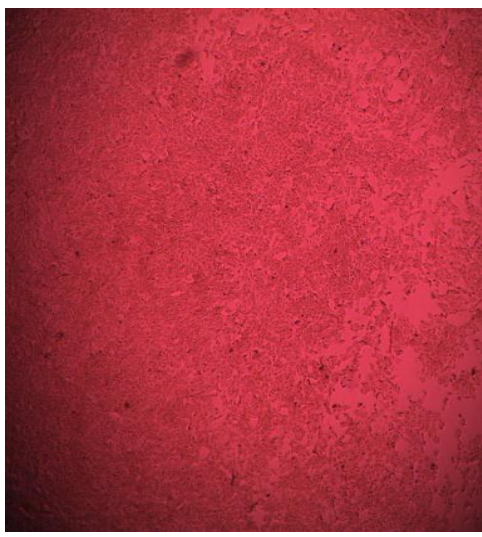

Fig.1l. Ethyl - Roots $(100 \mu \mathrm{g} / \mathrm{ml})$

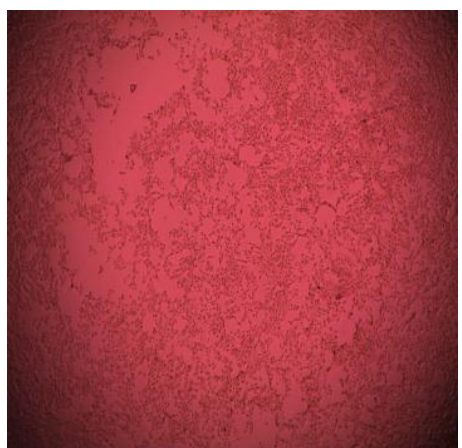

Fig. 1g. Ethyl-Leaves $(200 \mu \mathrm{g} / \mathrm{ml})$

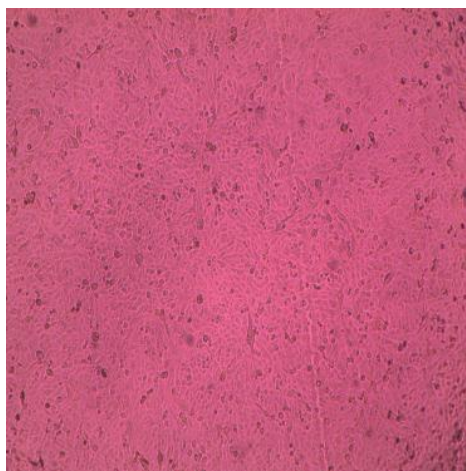

Fig. 1j. Aqua Roots $(200 \mu \mathrm{g} / \mathrm{ml})$

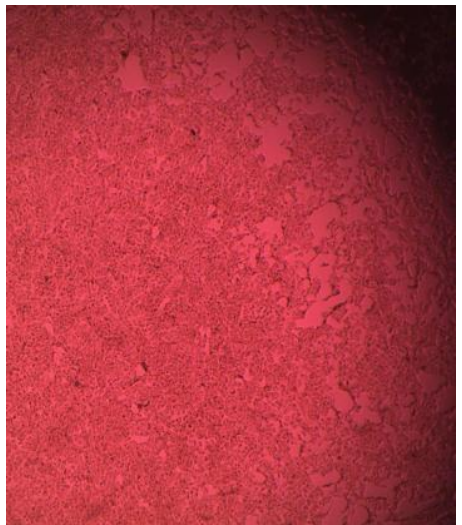

Fig.1m. Ethyl - Roots $(200 \mu \mathrm{g} / \mathrm{ml})$

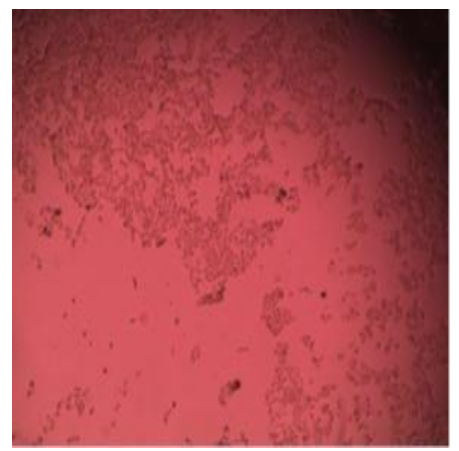

Fig. 1h. Ethyl-Leaves (400 $\mu \mathrm{g} / \mathrm{ml})$

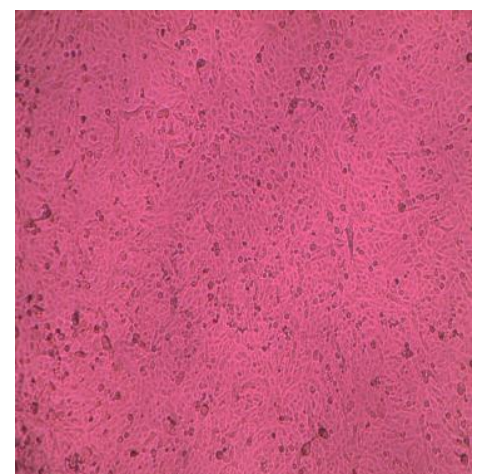

Fig. 1k. Aqua Roots $(400 \mu \mathrm{g} / \mathrm{ml})$

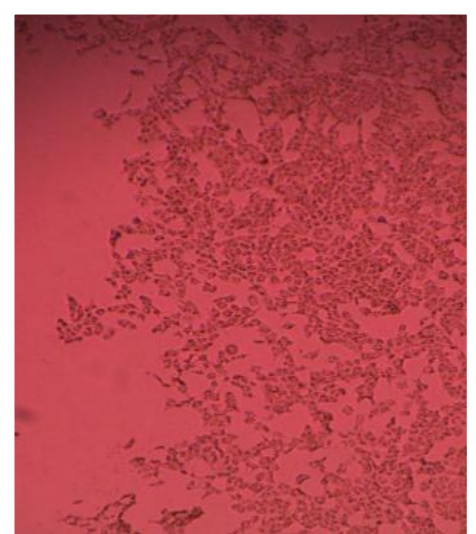

Fig.1n. Ethyl - Roots $(100 \mu \mathrm{g} / \mathrm{ml})$
Identification and quantification of flavonoids compounds of Moringa olifera Lam. (leaves and roots) aqueous and ethyl acetate extracts by HPLC.

Moringa olifera Lam. extracts were subjected to HPLC analysis to investigate the types of flavonoid compounds responsible for their antioxidant, anti lipidemic and anti-carcinogenic activities. In this investigation, $18 \pm 4$ flavonoid compounds were identified and quantified in Moringa olifera Lam. and its extracts by comparing the HPLC chromato- grams of them with the HPLC chromatograms of standard compounds based on the retention time. The obtained data were listed in Table (3). Flavonoids which identified were naringin, hespirdin, naringin, kampferol, quercetin and other flavonoids.

Remarkable data analysis of both extracts revealed higher content of most flavonoid compounds in Moringa in two extracts, In case, of flavonoid compounds in aqua-leaves extract showed the highest values of flavonoid compounds (17) containing naringin (1678.33ppm) and rutin 
(1557.81ppm) with high concentration comparing with ethyl-leaves extract naringin(82.03 ppm) and rutin (173.63ppm), also, high level of apig. 6arabinose-8-galactose (832.44ppm), luteo.7glucose (619.02 ppm), apigenin-7-glucose (409.74 ppm) and acacetin neo-rutinoside (520.57 ppm) found in aqua-leaves extract comparing with ethylleaves were recorded apig. 6-arabinose-8galactose (94.25 ppm), apigenin-7-glucose (36.93 ppm) and no detection were found in acacetin neorutinoside and luteo.7-glucose flavone. On the other hand, flavones were found in aqua- leaves extract but in low concentration such as quercetrin (281.16 ppm), kamp. 3,7-dirhamoside (258.50 ppm), apig.6-rhamnose-8-glucose (254.54 ppm), hespirtin (163 ppm), quercetin (119.41 ppm), rhamentin (133.26 ppm), naringenin (62.75 ppm), finally kampferol (15.49 ppm) and apegnin (25.22 ppm) comparing with ethyl-leaves extract quercetrin (87.7ppm), kamp.3,7-dirhamoside (97.41ppm), apig.6-rhamnose-8-glucose (95.31ppm), hespirtin (72.51 ppm), quercetin (101.1ppm), finally kampferol (28.20 ppm)and apegnin (15.73 ppm) but rhamentin, naringenin flavon not detected in this extract.

Table 3. Value of flavonoids compounds in Moringa oliefera Lam. leaves and roots determined by HPLC analysis.

\begin{tabular}{|l|c|c|c|c|}
\hline \multicolumn{4}{|c|}{ HPLC analysis } \\
\hline \multicolumn{2}{|c|}{ Test results of flavonoids (ppm) } \\
\cline { 2 - 5 } Flavonoids & Aqueous & $\begin{array}{c}\text { Ethyl } \\
\text { acetate }\end{array}$ & Aqueous & $\begin{array}{c}\text { Ethyl } \\
\text { acetate }\end{array}$ \\
\hline Apig. 6-arabinose-8- & 832.44 & 94.25 & 169.42 & 969.11 \\
Galactose & & & & \\
Apig. 6-rhamnose-8- & 254.54 & 95.31 & 78 & 213.79 \\
Glucose & & & & \\
Naringin & 1678.33 & 82.03 & 330.18 & 596.78 \\
Luteo.7-glucose & 619.02 & ND & 584.50 & 203.04 \\
Hesperidin & ND & 1145.97 & 1689.75 & 3123.15 \\
Rutin & 1557.81 & 173.63 & 144.66 & 423.18 \\
Apig.7-o-neo hespi- & 547.88 & 46.76 & 102.32 & 164.85 \\
roside & & & & \\
Kamp.3,7- dirhamo- & 258.50 & 97.41 & 54.37 & 83.14 \\
side & & & & \\
Quercetin & 281.16 & 87.69 & 92.29 & 479.07 \\
Apigenin-7-glucose & 409.74 & 36.93 & 18.19 & 57.64 \\
Acacetin & 102.22 & 53.71 & 116.41 & 382.27 \\
neo.hesperside & & & & \\
Acacetin neo. ruti- & 520.57 & ND & ND & ND \\
noside & & & & \\
Quercetin & 119.41 & 101.11 & 48 & 155.63 \\
Naringenin & 62.75 & ND & 37.64 & 74.94 \\
Hespirtin & 163.01 & 72.51 & 68.45 & 498.97 \\
Kampferol & 15.49 & 28.20 & 12.75 & 77.83 \\
Rhamentin & 133.26 & ND & ND & 142.93 \\
Apegnin & 25.22 & 15.73 & 15.16 & 28.19 \\
\hline All values were the & & & \\
\hline
\end{tabular}

All values were the mean of two injections

In case of roots extracts data recorded that, ethyl-roots extract show highest concentration of flavonoids such as hesperidin (3123.15 ppm) comparing with aqua-roots (1689.75 ppm). Also, shows high concentration in this extract as follow apig.6arabinose-8-galactose (969.11 ppm), naringin (596.7 ppm), hespirtin (498.97ppm), quercetin (479 ppm), rutin (423ppm), acacetin neo. hesperside (382.27 ppm), quercetin (155.63 ppm), follow by low concentration of kampferol (77.83 ppm), and naringenin (74.94 ppm) and apegnin (28.19 ppm) comparing with aqua-roots extract were shows apig.6-arabinose-8-galactose(169.4 ppm), naringin (330 ppm), hespirtin (68.45 ppm), quercetrin (92.29 ppm), rutin(144 ppm), acacetin neo. hesperside (116.4 ppm), quercetin(48 ppm), follow by low concentration of kampferol (12.75 ppm), and naringenin (37.64 ppm) and apegnin (15.16 ppm) finally, there is no detection for acacetin neo. rutinoside in both aqua-roots and ethyl-roots extracts.

In dried leaves, myricetin is found with low concentration, while kaempferol and quercetin are found with medium concentrations, whereas, higher amounts are presented in freeze-dried leaves (Siddhuraju \& Becker, 2003 and Amaglo et al 2010). Yang et al (2008) reported that flavonoids, for example apigenin, genistein and luteolin are not found in M. oleifera leaves. Modi et al (2010) illustrated that all parts of $M$. oleifera Lam. has combination between flavonoids and phenolic compounds, which treatment of numerous diseases for human.

Table 4. Values of Phenolic compounds in Moringa oliefera Lam. Leaves and roots determined by HPLC analysis.

\begin{tabular}{|l|l|c|c|c|}
\hline \multicolumn{5}{|c|}{ TPLC analysis } \\
\hline \multirow{3}{*}{ Phenolic compounds } & \multicolumn{2}{|c|}{ Leaves } & \multicolumn{2}{c|}{ Roots } \\
\cline { 2 - 5 } & Aqueous & $\begin{array}{c}\text { Ethyl } \\
\text { acetate }\end{array}$ & Aqueous & $\begin{array}{c}\text { Ethyl } \\
\text { acetate }\end{array}$ \\
\hline Gallic Acid & 176.75 & 3.02 & 97.11 & 446.78 \\
Pyrogallol & 2799.80 & 232.51 & 3288.70 & 46913.55 \\
4-Amino-benzoic acid & ND & 3.17 & 19.63 & 93.86 \\
Protocatchein & ND & 42.87 & 539.86 & 710.97 \\
Catchein & 4349.36 & 172.38 & 652.88 & 2169.34 \\
Chlorogenic acid & 169.75 & 66.48 & 161.34 & 458.24 \\
Catechol & 2157.05 & 121.64 & 11622.83 & 1321.27 \\
Caffeine & 240.30 & 81.45 & 157.97 & 928.37 \\
p-OH-benzoic acid & 951.20 & 229.94 & 269.32 & 1096.26 \\
Caffeic ccid & 80.99 & 18.14 & 116.25 & ND \\
Vanillic acid & 295.84 & ND & 119.19 & 889.57 \\
p-Coumaric acid & 90.23 & 76.05 & 23.80 & 164.21 \\
Ferulic acid & 234.09 & 99.66 & 65.70 & 360.19 \\
Iso-Ferulic acid & 54.26 & 16.79 & 15.71 & 131.39 \\
Alpha-coumarin & 114.08 & 14.79 & 35.81 & ND \\
Ellagic acid & ND & 77.15 & ND & 1338.60 \\
Benzoic acid & 825.34 & 460.67 & 1152.47 & 1778.92 \\
Coumarin & 282.46 & 41.46 & 136.12 & 463.27 \\
Coumarin-3,4,5- & 121.89 & ND & 44.55 & ND \\
tri.methoxy & & & & \\
Salycilic acid & 280.86 & 192.42 & 974.70 & 1163.07 \\
Cinnamic acid & 64.21 & 9.54 & 15.0 & 51.94 \\
\hline
\end{tabular}

All values were the mean of two injections. 

cytotoxicity of MCF-7 cell line

Identification and quantification of phenolic compounds of Moringa olifera Lam. (leaves and roots) aquouse and ethyl acetate extracts by HPLC.

Moringa olifera Lam. extracts were subjected to HPLC analysis to investigate the types of phenolic compounds responsible for their antioxidant and anti-carcinogenic activities. In this investigation, $21 \pm 4$ phenolic compounds were identified and quantified in Moringa olifera Lam. and its extracts by comparing the HPLC chromatograms of them with the HPLC chromatograms of standard compounds based on the retention time. The obtained data were listed in Table (4). Phenolic compounds which identified were gallic, pyrogallol, caechin and chlorogenic and other phenols.

Remarkable data analysis of both extracts revealed higher content of most phenolic and flavonoids compounds in Moringa in two extracts, In case, of phenolic compounds Pyrogallol compound showed the highest level of phenolic compounds in both extracts of roots and leaves. On the other hand, aqueous extract of root showed higher contents of phenolic compound except Ellagic acid which detected in ethyl acetate extract for both leaves and roots.

Coumarin 3, 4, 5 tri-methoxy not detected in ethyl acetate extracts. Chlorogenic, caffeine, caffic acid, vanillic and coumarine contents were found in moderate concentrations but, content of $p$ coumaric, ferulic acid, iso-ferulic and alfacoumarine were found in low concentration, as well as cinnamic acid were detected in lower concentration in both extracts.

Oboh et al (2015) memorized that Gallic and chlorogenic acid, kaempferol, and quercetin are compounds of phenolic found in the leaves extract.

Prakash et al (2007) and Singh et al (2009) reported that dried leaves containing, gallic acid, chlorogenic and caffeic with low concentration but, ratable concentrations were found for ellagic and ferulic acids. Also, Bajpai et al (2005) noted the poorly detectable amounts from this compounds .

In this case, the maximum studies difference for flavonoids and phenolic compounds probably due to variation of environmental conditions extraction method and sensitivity of the analytical methods.

Generally it can be noticed that flavonoids and phenolic compounds are believed to be the major phytochemicals responsible for antioxidant activity resulting to their scavenging ability due to their hydroxyl groups and also, acted the following pharmaceutical roles:

1. Kaempaferol has been reported to possess antioxidant and anti-inflammatory activity (karthivashan et al 2013).

2. chlorogenic acid has many biological properties, including antibacterial, antioxidant, particularly anticarcinogenic activities (Bassoli et al 2008 and Santos et al 2006).

\section{REFERENCE}

Abass, M.A., Kabbashi, A.S. and Garbi, M.I. 2015. In-vitro Antioxidant Activity, Phytochemical analysis and Cytotoxicity of Ethanolic leaves Extract of Moringa oleifera lam. In vitro, 2(11), 73-77.

Abd-Rabou, A.A., Zoheir, K.M., Kishta, M.S., Shalby, A.B. and Ezzo, M.I. 2016. Nanomicelle of moringa oleifera seed oil triggers mitochondrial cancer cell apoptosis. Asian Pacific journal of cancer prevention: APJCP, 17(11), 4929-4933.

Ahmed H.H., Abd-Rabou A.A., Hassan A.Z. and Kotob S.E. 2015. Phytochemical analysis and anti-cancer investigation of boswellia serrata bioactive constituents in-vitro. Asian Pac. J. Cancer Prev. 16, 7179-7188.

Bajpai, M., Pande, A., Tewari, S.K., and Prakash, D. 2005. Phenolic contents and antioxidant activity of some food and medicinal plants. International Journal of Food Sciences and Nutrition, 56(4), 287-291.

Bassoli, B.K., Cassolla, P., Borba-Murad, G.R., Constantin, J., Salgueiro-Pagadigorria, C. L., Bazotte, R.B. and de Souza, H.M. 2008. Chlorogenic acid reduces the plasma glucose peak in the oral glucose tolerance test: effects on hepatic glucose release and glycaemia. Cell Biochemistry and Function, 26(3), 320-328.

Chumark P., Khunawat P., Sanvarinda Y., Phornchirasilp S., Morales N.P., Phivthongngam L., Ratanachamnong P., Srisawat S. and Pongrapeeporn K.S. 2008. The in- vitro and ex-vivo antioxidant properties, hypolipidaemic and antiatherosclerotic activities of water extract of Moringa oleifera Lam Leaves. J. Ethnopharmacol. 116, 439-446.

Das, S.K., Khan, M.M.R., Guha, A.K., Das, A.R., and Mandal, A.B. 2012. "Silver-nano biohybride material: synthesis, characterization and application in water purification." Bioresource Technology 124, 495- 499. 
Fahey J.W. 2005. Moringa oleifera: A review of the medical evidence for its nutritional, therapeutic, and prophylactic properties. Trees for Life $\mathbf{J}$. 1(5), 1-15.

Fuglie, L.J. 1999. The miracle tree: Moringa oleifera, natural nutrition for the tropics. Church World Service, Dakar (Seghal) eng. 68 p.

Gao X., Xu Y.X., Divine G., Janakiraman N, Chapman R.A. and Gautam S.C., 2002. Disparate in-vitro and in-vivo antileukemic effects of resveratrol, a natural polyphenolic compound found in grapes. J. Nutr. 132, 2076-2081.

Goodman G.E. 2000. Lung cancer 1: Prevention of lung cancer. Thorax, 57(11), 994-999.

Goupy, P., Hugues, M., Boivin, P. and Amiot, M. J. 1999. Antioxidant composition and activity of barley (Hordeum vulgare) and malt extracts and of isolated phenolic compounds. J. Science of Food and Agriculture, 79(12), 16251634.

Gupta M., Mazumder U.K. and Chakrabarti S.C.N.S., 1999. Activities of methanolic extract of Moringa oleifera root in mice. Fitoterapia, 70, 244-250.

Harborne, J.B. 1984. Phytochemical Methods. (3 ${ }^{\text {rd }}$ Ed.). A guide to modern techniques of plant analysis. Chapman and Hall Co. New York, USA, pp. 4-8.

Igbo, U.E., Igoli, J.O., Onyiriuka, S.O., Ejele, A.E., Ogukwe, C.E., Ayuk, A.A. and Gray, A.I. 2015. Antitrypanosomal and antioxidant activities of Moringa oleifera lam leaf extracts. J. Pharm. Chem. Biol Sci., 3(1), 17-23.

Iqbal S. and Bhanger M.I. 2006. Effect of season and production location on antioxidant activity of Moringa oleifera leaves grown in Pakistan. $\mathbf{J}$. Food Compos. Anal. 19, 544-555.

Jain, A., Soni, M., Deb, L., Jain, A., Rout, S., Gupta, V and Krishna, K. 2008. Antioxidant and hepatoprotective activity of ethanolic and aqueous extracts of Momordica dioica Roxb. leaves. J. Ethnopharmacology 115(1), 61-66.

Karthivashan, G., Tangestani Fard, M., Arulselvan, P., Abas, F. and Fakurazi, S. 2013. Identification of bioactive candidate compounds responsible for oxidative challenge from hydro-ethanolic extract of Moringa oleifera leaves. J. Food Science, 78(9), 1368-1375.

Khalafalla, M.M., Abdellatef, E., Dafalla, H.M., Nassrallah, A.A., Aboul-Enein, K.M., Lightfoot, D.A., and El-Shemy, H.A. 2010. Active principle from Moringa oleifera Lam leaves effective against two leukemias and a hepatocarcinoma. African J. Biotechnology,9(49),84678471.
Lalas S. and Tsaknis J. 2002. Extraction and identification of natural antioxidant from the seeds of the Moringa oleifera tree variety of Malawi. JAOSC 79, 677-683.

Leelavinothan, P., Karamać, M., Kosińska, A., Rybarczyk, A. and Amarowicz, R. 2007. Antioxidant activity of the crude extracts of drumstick tree (Moringa oleifera Lam.) and sweet broomweed (Scoparia dulcis L.) leaves. Polish Journal of Food and Nutrition Sciences, 57(2), 203-208.

Modi, D., Patel, J., Shah, B. and Nayak, B. 2010. Phytopharmacology of Moringa Oleifera-An Edible Plant 2, 692-705.

Oboh, G., Ademiluyi, A.O., Ademosun, A.O., Olasehinde, T.A., Oyeleye, S.I., Boligon, A.A. and Athayde, M.L. 2015. Phenolic extract from Moringa oleifera leaves inhibits key enzymes linked to erectile dysfunction and oxidative stress in rats' penile tissues. Biochemistry Research International, pp. 1-8.

Peixoto, J.R.O., Silva, G.C., Costa, R.A., de Sousa Fontenelle J.L., Vieira, G.H.F., Fonteles Filho, A.A., and dos Fernandes Vieira, R.H.S. 2011. In vitro antibacterial effect of aqueous and ethanolic Moringa leaf extracts. Asian Pacific J. Tropical Medicine, 4(3), 201-204.

Prakash, D., Suri, S., Upadhyay, G. and Singh, B.N. 2007. Total phenol, antioxidant and free radical scavenging activities of some medicinal plants. Int. J. Food Sci. Nutr, 58, 18-28.

Repetto, G., Del Peso, A., and Zurita, J. L. 2008. Neutral red uptake assay for the estimation of cell viability/cytotoxicity. Nature Protocols, 3(7), 1125-1131.

Santos, N.C., Ecuvillon, A., Israelian, G., Mayor, M., Melo, C., Queloz, D. and Jorge, S. 2006. Chemical abundances for the transiting planet host stars OGLE-TR-10, 56, 111, 113, 132, and TrES-1-Abundances in different galactic populations. Astronomy \& Astrophysics, 458(3), 997-1005.

Siddhuraju, P. and Becker, K. 2003. Antioxidant properties of various solvent extracts of total phenolic constituents from three different agroclimatic origins of drumstick tree (Moringa oleifera Lam.) leaves. J. Agricultural and Food Chem., 51(8), 2144-2155.

Singh, B.N., Singh, B.R., Singh, R.L., Prakash, D., Dhakarey, R., Upadhyay, G. and Singh, H.B. 2009. Oxidative DNA damage protective activity, antioxidant and anti-quorum sensing 

cytotoxicity of MCF-7 cell line

potentials of Moringa oleifera. Food and Chemical Toxicology, 47(6), 1109-1116.

Singleton, V.L. and Rossi J.A., 1965. Colorimetry of total phenolics with phosphomolybdic- phosphotungstic acid reagents. American J. Enol. Vitic., 16, 144-158

Unuigbe, C.A., Okeri, H.A., Erharuyi, O., Oghenero, E.E. and Obamedo, D.A. 2015. Phytochemical and antioxidant evaluation of Moringa oleifera (Moringaceae) leaf and seed. J. Pharm. Bioresour, 11, 51-57.
Verma, P., Mathur, A.K., Srivastava, A. and Mathur, A. 2012. Emerging trends in research on spatial and temporal organization of terpenoid indole alkaloid pathway in Catharanthus roseus: a literature update. Protoplasma, 249 (2), 255-268.

Yang, R.Y., Yang, R.Y., Lin, S. and Kuo, G. 2008. Content and distribution of flavonoids among 91 edible plant species. Asia Pac. J. Clin. Nutr., 17, 275-279. 

المؤتمر الرابع عثر لبحوث التنمية الزراعية،

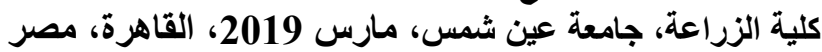

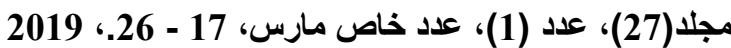

MCF-7 تقيم المركبات الفينولية فى مستخلصات نبات المورينجا على التسمم الخلوى للخلايا

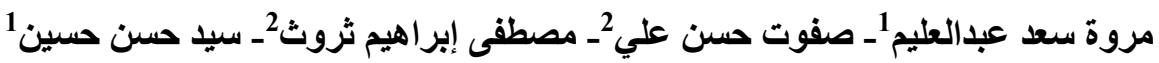

1. قسم النباتات الطبية والعطرية- معهد بحوث البساتين- مركز البحوث الزراعية- جيزة- مصر

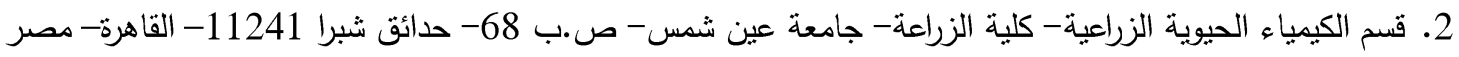

“Corresponding author: marwa.saad54@yahoo.com

Received 18 February, 2019,

Accepted 21 February, 2019

أدت إلى زيادة النسبة المئوية للتثبيط لخلايا MCF-7

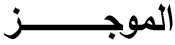

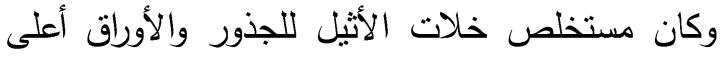

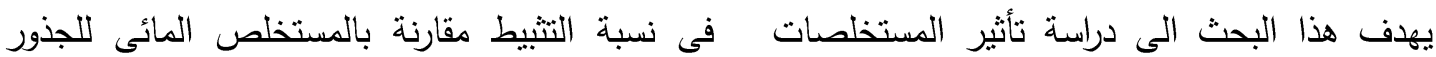

المائية والعضوية لخلات الأيثيل على جذور وأوراق والألئ لأوراق.

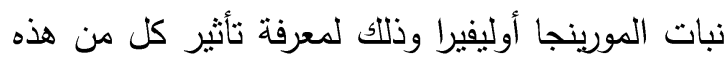

الكلمات الدالة: المورينجا أوليفيرا، المستخلصات المائية المستخلصات على خلايا MCF-7 وأظهرت الكئن النتائج والعضوية، خط الخلايا MCF-7 أن المستخلصات المائية والعضوية لخلات الاثيل قدائ 